\title{
PENGARUH PEMBERIAN MADU TERHADAP RESPON NYERI ANAK USIA SEKOLAH YANG DILAKUKAN TINDAKAN INVASIF DI RSUD WATES KULON PROGO
}

\author{
Adesti Ratna Pratiwi ${ }^{1}$, Afi Lutfiyati ${ }^{1}$, Dwi Yati ${ }^{1}$ \\ SekolahTinggi Ilmu Kesehatan Jenderal Achmad Yani Yogyakarta
}

\begin{abstract}
Background: Invasive therapy is an unpleasant process especially for children, due to its pain effect. Poor awareness on pain and trauma in children for a long period may cause disadvantage in children's growth and development. One of the non pharmacological pain relief managements in children is glucose intake or other sugar substitutes such as honey which consists of flavonoid to relieve pain.

Objective: To identify the influence of honey application on pain response in school-aged children during invasive intervention in Wates Regional General Hospital of Kulon Progo.

Method: This study was quasy experiment with post-test and non equivalent control group design. Statistical test applied non-parametric test of Mann Whitney with significance level of $a=0,05$. Samples were selected through purposive sampling technique, consisted of 34 respondents. The study used pure (100\%) honey. Five mililiter of honey was administered two minutes prior to invasive intervention.

Result: The result figured out $p$-value of $0.001(p<0.05)$ which indicated that there was an influence of honey application on pain response in school-aged children during invasive intervention in Wates Regional General Hospital of Kulon Progo.

Conclusion: Honey had an influence on relieving pain during the invasive intervention in school-aged children.
\end{abstract}

Keywords: Invasive intervention, Pain level, Honey

\section{PENDAHULUAN}

Keadaan anak yang tiba-tiba sakit atau cedera mengharuskan anak untuk dibawa ke ruang unit instalasi gawat darurat (IGD). Instalasi gawat darurat memberikan pelayanan dengan respon cepat dan penanganan yang tepat. ${ }^{(1)}$ Hospitalisasi merupakan suatu proses di mana karena alasan tertentu atau darurat mengharuskan anak untuk tinggal di rumah sakit, menjalani terapi perawatan sampai pemulangannya kembali ke rumah. ${ }^{(2)}$

Salah satu faktor stress bagi anak semua usia adalah prosedur yang menyakitkan atau tindakan invasif karena anak sedang sakit dan harus dirawat di rumah sakit, mereka akan menjalani berbagai macam prosedur invasif seperti pemasangan infus dan pengambilan sampel darah sebagai upaya untuk mengobati penyakit yang diderita oleh anak. ${ }^{(2)}$ Walco meneliti tentang prevalensi nyeri dan sumber utama penyebab nyeri pada 200 anak yang dirawat di rumah sakit anak. Hasil tindakan medis IV (intravena) menduduki tindakan pertama. Walco juga mengevaluasi hasil penelitiannya berdasarkan tingkatan umur dan diperoleh bahwa distress paling tinggi yaitu $83 \%$ dialami oleh anak toddler, distres cukup tinggi dialami oleh anak usia sekolah yaitu $51 \%$ serta remaja dengan prevalensi $28 \%$. Hal ini menunjukkan bahwa anak toddler dan usia sekolah merasa distres yang cukup tinggi terhadap nyeri. ${ }^{(3)}$ Penatalaksanaan nyeri dapat berupa tindakan nonfarmakologi menurut Buonocore dan Bellienipada bayi atau anak dapat berupa sweet solution (glukosa dan 
sukrosa). ${ }^{(4)}$ Ghofur \& Mardalena menjelaskan bahwa minuman yang manis mempunyai mekanisme potensial yang dapat mengurangi nyeri karena dapat merangsang mengeluarkan opioid endogen pada sistem syaraf pusat. ${ }^{(5)}$ Salah satu sumber rasa manis yang banyak mengandung glukosa dan sukrosa adalah madu. Madu merupakan bahan makanan energi yang baik karena mengandung gula-gula sederhana yang dapat dimanfaatkan tubuh. ${ }^{(6)}$

Geonarwo et al. menyebutkan kandungan flavonoid yang terdapat dalam madu dapat menghambat nyeri yaitu dengan mekanisme kerja menghambat pembentukan prostaglandin melalui penghambatan enzim cyclooxygenase sama seperti obat-obat analgesik antipiretik lain. ${ }^{(7)}$ Masalah dalam penelitian ini adalah apakah madu berpengaruh dalam menurunkan nyeri anak usia sekolah.

\section{BAHAN DAN CARA PENELITIAN}

Penelitian ini merupakan jenis penelitian eksperimen semu (quasy experiment). Rancangan penelitian menggunakan jenis posttestonlynonequivalent control group design. Sampel dalam penelitian ini menggunakan teknik purposive sampling dengan responden sebanyak 34. Penelitian dilakukan di ruang IGD dan Cempaka RSUD Wates Kulon Progo. Alat dan bahan yang digunakan adalah madu murni $100 \%$, air putih, tissue, sendok makan, spuit 5cc, dan gelas. Instrumen yang digunakan adalah skala Visual Analogue Scale (VAS).

HASIL DAN PEMBAHASAN

Tabel 1 Karakteristik Responden

\begin{tabular}{|c|c|c|c|c|c|c|c|}
\hline \multirow{2}{*}{ Karakteristik } & \multicolumn{2}{|c|}{ Kontrol } & \multicolumn{2}{|c|}{ Intervensi } & \multicolumn{2}{|c|}{ Total } & \multirow{2}{*}{$p$ value } \\
\hline & $\mathrm{n}$ & $\%$ & $\mathrm{n}$ & $\%$ & $\mathrm{n}$ & $\%$ & \\
\hline \multicolumn{8}{|l|}{ Usia } \\
\hline 6 tahun & 1 & 5,9 & 2 & 11,8 & 3 & 8,8 & \multirow{7}{*}{0,997} \\
\hline 7 tahun & 6 & 35,3 & 2 & 11,8 & 8 & 23,5 & \\
\hline 8 tahun & 2 & 11,8 & 3 & 17,6 & 5 & 14,7 & \\
\hline 9 tahun & 2 & 11,8 & 3 & 17,6 & 5 & 14,7 & \\
\hline 10 tahun & 2 & 11,8 & 2 & 11,8 & 4 & 11,8 & \\
\hline 11 tahun & 3 & 17,6 & 3 & 17,6 & 6 & 17,6 & \\
\hline 12 tahun & 1 & 5,9 & 2 & 11,8 & 3 & 8,8 & \\
\hline \multicolumn{8}{|l|}{ Jenis Kelamin } \\
\hline Laki-laki & 8 & 47,1 & 13 & 76,5 & 21 & 61,8 & \multirow[t]{2}{*}{0,613} \\
\hline Perempuan & 9 & 52,9 & 4 & 23,5 & 13 & 38,2 & \\
\hline \multicolumn{8}{|l|}{ Pengalaman } \\
\hline Sebelumnya & & & & & & & \multirow{3}{*}{0,39} \\
\hline Pernah & 8 & 47,1 & 10 & 58,8 & 18 & 52,9 & \\
\hline Tidak pernah & 9 & 52,9 & 7 & 41,2 & 16 & 47,1 & \\
\hline \multicolumn{8}{|l|}{ Tindakan Invasif } \\
\hline Pemasangan infus & 10 & 58,8 & 11 & 64,7 & 21 & 61,8 & \multirow{2}{*}{0,52} \\
\hline $\begin{array}{l}\text { Pengambilan sampel } \\
\text { darah }\end{array}$ & 7 & 41,2 & 6 & 35,3 & 13 & 38,2 & \\
\hline
\end{tabular}


Tabel 2 Skala Nyeri Tindakan Invasif Setelah Pemberian Madu Pada Kelompok Intervensi

\begin{tabular}{ccc}
\hline \multicolumn{3}{c}{ Kelompok Intervensi } \\
\hline Kategori & $\begin{array}{c}\text { Frekuensi } \\
\text { Nyeri }\end{array}$ & $\begin{array}{c}\text { Persentase } \\
(\mathrm{n})\end{array}$ \\
\hline Ringan & 5 & $29)$ \\
Sedang & 12 & 70,6 \\
Berat & 0 & 0,0 \\
\hline Total & 17 & 100 \\
\hline
\end{tabular}

Tabel 3 Skala nyeri setelah tindakan invasif pada kelompok kontrol

\begin{tabular}{|c|c|c|}
\hline \multicolumn{3}{|c|}{ Kelompok Kontrol } \\
\hline $\begin{array}{c}\text { Kategori } \\
\text { Nyeri }\end{array}$ & $\begin{array}{l}\text { Frekuensi } \\
\text { (n) }\end{array}$ & $\begin{array}{c}\text { Persentase } \\
(\%)\end{array}$ \\
\hline Ringan & 0 & 0 \\
\hline Sedang & 3 & 17,6 \\
\hline Berat & 14 & 82,4 \\
\hline Total & 17 & 100 \\
\hline
\end{tabular}

Tabel 4 Pengaruh Pemberian Madu Terhadap Respon Nyeri Setelah Tindakan Invasif

\begin{tabular}{llllll}
\hline \multicolumn{5}{c}{ Post-test } \\
\hline $\begin{array}{l}\text { Kategori } \\
\text { Nyeri }\end{array}$ & $\begin{array}{l}\text { Kelompok } \\
\text { Intervensi } \\
(\mathrm{n})\end{array}$ & $\begin{array}{l}\text { Kelompok } \\
\text { Kontrol } \\
(\mathrm{n})\end{array}$ & $\begin{array}{l}\text { pol } \\
\text { (\%) }\end{array}$ & \\
\hline Ringan & 529,4 & 0 & 0,0 & \\
Sedang & 12 & 70,6 & 3 & 17,6 & 0,001 \\
Berat & 0 & 0,0 & 14 & 82,4 & \\
\hline Total & 17 & 100 & 17 & 100 & \\
\hline
\end{tabular}

\section{PEMBAHASAN}

\section{Karakteristik Responden}

Dari hasil penelitian diperoleh bahwa usia responden dalam penelitian ini anak usia sekolah 6-12 tahun. Pemilihan usia responden di atas usia 1 tahun karena untuk mencegah terjadinya keracunan botulismus dari bakteri clostridium botulinum. Menurut Potter\& Perryusia merupakan salah satu faktor yang dapat memengaruhi pengalaman nyeri sehingga juga dapat memengaruhi anak dalam bereaksi terhadap nyeri. ${ }^{\left({ }^{(8)}\right.}$
Hasil penelitian menunjukkan bahwa sebagian besar responden pada kelompok kontrol berjenis kelamin perempuan sebanyak 9 responden $(52,9 \%)$ dan kelompok intervensi sebagian besar berjenis kelamin laki-laki sebanyak 13 responden (76,5\%). Dari total sampel secara keseluruhan diperoleh bahwa responden berjenis kelamin laki-laki sebanyak 21 responden (61,8\%). Secara biologis (fisik) perempuan lebih lemah daripada laki-laki. Sedangkan perbedaan secara psikologis, perempuan lebih mudah tersinggung, mudah dipengaruhi, dan mudah meluapkan perasaan sementara laki-laki lebih rasional.

Secara umum laki-laki dan perempuan tidak berbeda dalam berespon terhadap nyeri tetapi toleransi terhadap nyeri dipengaruhi oleh faktor-faktor biokimia dan merupakan hal yang unik pada setiap individu tanpa memperhatikan jenis kelamin. ${ }^{(8)} \mathrm{Hasil}$ penelitian menunjukkan bahwa pada kelompok kontrol sebagian besar tidak pernah mengalami pemasangan infus dan pengambilan sampel darah sebanyak 9 responden $(52,9 \%)$ dan kelompok intervensi sebagian besar pernah mengalami pemasangan infus dan pengambilan sampel darah sebanyak 10 responden (58,8\%).

Hasil penelitian menunjukkan keseluruhan responden kelompok kontrol sebanyak 17 responden (100\%) dan kelompok intervensi sebanyak 17 responden (100\%) didampingi oleh orang tua. Menurut Potter dan Perry kehadiran keluarga ataupun teman terkadang 
dapat membuat pengalaman nyeri yang menyebabkan stres sedikit berkurang. Kehadiran orang tua sangat penting bagi anak-anak yang mengalami nyeri. ${ }^{\left({ }^{(8)}\right.}$

\section{Gambaran Skala Nyeri Anak Usia Sekolah} Setelah Dilakukan Tindakan Invasif pada Kelompok Intervensi

Skala nyeri setelah pemberian madu pada kelompok intervensi sebagian besar termasuk kategori nyeri sedang sebanyak 12 responden (70,6\%). Theory gate control menjelaskan bahwa impuls nyeri dapat diatur atau bahkan dihambat oleh mekanisme pertahanan di sepanjang sistem saraf pusat. Mekanisme pertahanan dapat ditemukan di sel-sel gelatinosa substansia di dalam kornu dorsalis pada medulla spinalis, thalamus, dan sistem limbik. Teori ini mengatakan bahwa impuls nyeri dihantarkan saat sebuah pertahanan tertutup. Upaya menutup pertahanan tersebut merupakan dasar terapi menghilangkan nyeri.

Tubuh juga melakukan mekanisme kimia untuk memanajemen nyeri. Serabut di dorsal horn, batang otak, dan jaringan perifer mengeluarkan opioid endogen yang menghambat aksi neuron yang mentransmisikan impuls nyeri. Opioid endogen menutup mekanisme pertahanan dengan menghambat pelepasan substansi $\mathrm{P} .{ }^{(8)}$ Penanganan nyeri akibat tindakan invasif secara nonfarmakologi dapat berupa pemberian rasa manis (glukosa dan sukrosa). ${ }^{(4)}$
Penatalaksanaan mengurangi nyeri pada anak dengan tindakan nonfarmakologi yang paling efektif adalah pemberian glukosa atau pemanis lainnya saat tindakan yang menyebabkan nyeri karena pada dasarnya anak-anak lebih menyukai rasa manis. ${ }^{(9)}$ Ghofur \& Mardalena menjelaskan bahwa minuman yang manis memunyai mekanisme potensial yang dapat mengurangi nyeri karena dapat merangsang mengeluarkan opioid endogen pada sistem syaraf pusat. ${ }^{(5)}$ Penelitian yang dilakukan Dewi menjelaskan bahwa perbedaan yang signifikan antara derajat nyeri saat pemasangan infus setelah diberikan air steril dan sukrosa $24 \%$. $^{(10)}$

Salah satu sumber rasa manis yang banyak mengandung glukosa dan sukrosa adalah madu. Madu merupakan bahan makanan energi yang baik karena mengandung gula-gula sederhana yang dapat dimanfaatkan tubuh. ${ }^{(6)}$ Kandungan flavonoid yang terdapat dalam madu dapat menghambat nyeri yaitu dengan mekanisme kerja menghambat pembentukan prostaglandin melalui penghambatan enzim cyclooxygenase sama seperti obat-obat analgesik antipiretik lain. ${ }^{(7)}$

\section{Gambaran Skala Nyeri Anak Usia Sekolah} Setelah Dilakukan Tindakan Invasif pada Kelompok Kontrol

Skala nyeri setelah tindakan invasif pada kelompok kontrol sebagian besar termasuk dalam kategori nyeri berat sebanyak 14 responden (82,4\%). Respon 
emosi terhadap penyakit sangat bervariasi tergantung pada usia dan pencapaian tugas perkembangan anak. ${ }^{(11)}$ Apabila tubuh merasakan nyeri, reaksi yang akan dialami pada anak adalah menangis, menyeringaikan wajah, mengatupkan gigi, menggigit bibir, membuka mata dengan lebar, menendang, memukul, atau berlari keluar. ${ }^{(12)}$ Salah satu faktor stres bagi anak semua usia adalah prosedur yang menyakitkan atau tindakan invasif seperti pemasangan infus dan pengambilan sampel darah. ${ }^{(2)}$ Nyeri yang ditimbulkan akibat tindakan invasif bersifat subjektif karena nyeri berbeda tiap orang, hanya orang tersebut yang dapat menjelaskan rasa nyeri yang dialaminya. ${ }^{(11)}$

Nyeri disebabkan karena energi kimia, suhu, mekanik yang menyebabkan nyeri diubah menjadi energi listrik sehingga akan mengakibatkan pelepasan prostaglandin yang menghantarkan impuls nyeri dari neuron sensorik. Substansi yang peka terhadap nyeri akan menyebarkan "pesan" adanya nyeri dan menyebabkan inflamasi. Kemudian seseorang sadar akan nyeri sehingga orang tersebut akan bereaksi berupa respon perilaku dan respon fisiologis. Respon fisiologis berupa peningkatan tekanan darah, pernafasan, nadi, wajah pucat, dan berkeringat. Apabila nyeri dan trauma dibiarkan maka akan berlangsung lama pada anak sehingga dapat mengganggu pertumbuhan dan perkembangan anak. ${ }^{(13)}$

\section{Pengaruh Pemberian Madu terhadap Respon Nyeri Setelah Tindakan Invasif}

Hasil penelitian menunjukkan bahwa ada pengaruh pemberian madu terhadap respon nyeri tindakan invasif dengan nilai $p$ value $0,001 \quad(<0,05)$. Hal ini mungkin disebabkan karena rasa manis madu, kandungan glukosa dan sukrosa pada madu, dan kandungan flavonoid pada madu yang dapat menurunkan nyeri. Penelitian Dewi (2014) membandingkan pemberian air steril per oral dengan sukrosa $24 \%$ diberikan 2 menit sebelum tindakan pemasangan infus pada noenatus di RS Ibnu Sina Pekanbaru. Hasil penelitian menyebutkan bahwa sukrosa $24 \%$ efektif terhadap respon nyeri akut pada neonatus yang dilakukan tindakan pemasangan infus dengan nilai $p$ value 0,020 $(p<0,05)$. Penilaian skor nyeri menggunakan Premature Infant Pain Profile (PIPP).

Penelitian lain dilakukn oleh Ulfah memberikan larutan gula 1 menit sebelum tindakan pungsi vena dan dipertahankan selama tindakan pada anak usia 3-4 tahun di RSUD Tugurejo Semarang dengan menggunakan penilaian skor nyeri Face, Legs, Activity, Cry, Consolability ${ }_{(F L A C C)}{ }^{(9)}$

Hasil penelitian menunjukkan ada pengaruh yang signifikan antara pemberian larutan gula terhadap skala nyeri anak selama tindakan pungsi vena, terlihat bahwa ( $p$-value 0,$001 ; \alpha=0,05)$ dan Z-hitung 5,097 lebih besar dari nilai Z-tabel 5000. Penelitian 
lain Ghofur \& Mardalena dengan membandingkan glukosa $30 \%$, aqua, dan air susu ibu (ASI) pada bayi usia 6-12 bulan yang dilakukan imunisasi dasar di wilayah Puskesmas Gamping II, Sleman. ${ }^{(5)}$

Hasil penelitian menunjukkan pemberian glukosa pada saat imunisasi injeksi pada bayi tidak signifikan mengurangi respon nyeri berupa intensitas dan lama tangisan bayi tetapi signifikan mengurangi respon nyeri untuk denyut nadi. Penurunan respon nyeri dikarenakan glukosa atau pemanis oral lainnya bekerja dengan cara mengeluarkan opioid endogen melalui kelenjar perasa manis yang berada di porsio anterior lidah. Diperantai oleh stimulasi orotaktil yang meningkat oleh karena adanya kontak cairan dengan rongga oral dan merangsang pelepasan opioid endogen di sistem syaraf pusat yang berfungsi neurotransmitter analgesik. Endorpin akan memblokir pelepasan prostaglandin yang seharusnya menghantarkan impuls nyeri dari neuron sensorik sehingga transmisi nyeri terhambat dan sensasi nyeri berkurang. ${ }^{(14)}$

Madu merupakan bahan makanan energi yang baik karena mengandung gulagula sederhana yang dapat dimanfaatkan tubuh. ${ }^{(6)}$ Penelitian yang dilakukan Sekriptini dengan pemberian madu per oral 2 menit sebelum tindakan pengambilan darah intravena pada anak usia 1-6 tahun di ruang UGD RSUD Kota Cirebon. Hasil penelitian menunjukkan ada perbedaan yang berbeda antara rerata skor nyeri kelompok kontrol dan kelompok intervensi dengan nilai $p$-value 0,001 . Skor nyeri menggunakan Children's Hospital Of Eastern Ontario Pain Scale (CHEOPS). ${ }^{(15)}$

Penelitian lain dilakukan oleh Boroumand et al dengan pemberian madu pada post tonsillectomy anak usia 8-15 tahun di RS Zahedan, Iran. Hasil penelitian menunjukkan perbedaan antara acetaminophen dan kelompok acetaminophen ditambah madu adalah signifikan secara statistik baik untuk skala VAS (Visual Analogue Scale) dan jumlah obat analgesik yang diberikan selama tiga hari pertama pasca operasi. ${ }^{(16)}$ Hasil penelitian yang dilakukan Goenarwo et al. madu mempunyai efek analgetik pada tikus dan konsentrasi madu yang paling efektif adalah $50 \%(1,35 \mathrm{~g} / \mathrm{kgBB}) .{ }^{.7)}$

Almadamenjelaskan bahwa kandungan flavonoid dalam madu dapat mencegah produksi enzim cyclooxygenase. Enzim cyclooxygenase adalah suatu enzim yang mengkatalisis sintesis prostaglandin dari asam arakhidonat. Flavonoid memblok aksi dari enzim cyclooxygenase yang menurunkan produksi mediator prostaglandin, prostaglandin inilah yang akan menyebabkan nyeri sehingga nyeri akan berkurang. ${ }^{(17)}$

\section{KESIMPULAN}

Skala nyeri pada kelompok intervensi setelah dilakukan tindakan invasif sebagian besar termasuk kategori nyeri sedang 
sebanyak 12 responden (70,6\%). Skala nyeri pada kelompok kontrol setelah dilakukan tindakan invasif sebagian besar termasuk kategori nyeri berat sebanyak 14 responden $(82,4 \%)$. Ada pengaruh pemberian madu terhadap respon nyeri setelah tindakan invasif dengan nilai $p$ value $0,001(<0,05)$.

Bagi orangtua anak usia sekolah dapat memanfaatkan madu untuk mengatasi nyeri anak. Bagi perawat dapat menerapkan teknik nonfarmakologi dalam manajemen nyeri akibat tindakan invasif pada anak disesuaikan dengan tahap perkembangan anak.

Peneliti Selanjutnya, perlu dilakukan penelitian selanjutnya dalam pemberian madu per oral terhadap respon nyeri anak, nyeri post partum, atau nyeri sectio caesarea dengan instrumen yang berbeda.

\section{KEPUSTAKAAN}

1. Kartikawati, D. Buku Ajar DasarDasar Keperawatan Gawat Darurat.Jakarta: Salemba Medika. 2011.

2. Supartini, Y. Buku Ajar Konsep Dasar Keperawatan Anak. Jakarta: EGC. 2010.

3. Walco, G. Needle Pain in Children: Contextual Factors. Journal of theAmerica Academy of Pediatrics. 2008. Volume 19, No.1, Hal. 55-61.

4. Buonocore, G., \& Bellieni, C.V. Neonatal Pain: Suffering, Pain and Risk of Braindamage in the Fetus and
Newborn. Italia: Springer-Verlag. 2008.

5. Ghofur, A., dan Mardalena.I. Effect of Glucose on the Response Pain Baby InPuskesmas Gamping II Sleman Yogyakarta. 2014. Prosiding KonferensiNasional II PPNI Jawa Tengah. Hal. 36-42.

6. Sihombing, D, T.H. IImu Ternak Lebah Madu. Yogyakarta: Gadjah MadaUniversity Press. 2005.

7. Goenarwo, E., Chodijah., \& Susanto, H. Uji Efektifitas Analgetik Madu padaTikus dengan Metoda Geliat Asetat. 2011. E-Jurnal. Vol.3, No. 1, Hal.48-53.

8. Potter, P.A., and Perry, A.G. Fundamental Keperawatan. Jakarta: Salemba Medika. 2010.

9. Ulfah, S. Pengaruh Pemberian Larutan Gula Per Oral terhadap Skala Nyeri Anak Usia 3-4 Tahun yang Dilakukan Pungsi Vena DI RSUD Tugurejo Semarang. Jurnal IImu Keperawatan dan Kebidanan. 2014. Vol 1, No. 6, Hal. 1-10.

10. Dewi, R.S. Efektifitas Sukrosa Oral terhadap Respon Nyeri Akut padaNeonatus yang Dilakukan Tindakan Pemasangan Infus di RS Ibnu SinaPekanbaru. Jurnal Keperawatan Anak. 2014. Hal. 1-10.

11. Hidayat, A.A. Pengantar IImu Keperawatan Anak I. Jakarta: Salemba Medika. 2005. 
12. Nursalam., Susilaningrum., dan Utami. Asuhan Keperawatan Bayi dan Anak. Jakarta: Salemba Medika. 2005.

13. Tamsuri, A. Konsep \& Penatalaksanaan Nyeri. Jakarta: EGC. 2007.

14. Sherwood, L. FisiologiManusia: Dari SelkeSistem. Jakarta: EGC. 2011.

15. Sekriptini, A.Y. PengaruhPemberian Madu terhadapPenurunan Skor Nyeri Akibat Tindakan Invasif Pengambilan Darah Intravena pada Anak di Ruang UGD RSUD Kota Cirebon. Tesis. FIK Universitas Indonesia. 2013.

16. Boroumand, P., Zamani, M.M., Saeedi, M., Rouhbakhsfar, O., Motlagh, S., \& Moghaddam, F.A. Post Tonsillectomy Pain: Can Honey Reduce TheAnalgesic Requirements? 2013. Kowsar Corp. Hal. 198-202.

17. Almada, Natural COX-2 inhibitor the future of pain relief. International Chiropractic Pediatric Association. 2000. Pain News. Volume 10, No. 2, Hal 112-118. 